\title{
Hak Paten Desain Kamera Pop Up pada Vivo APEX
}

\author{
Nenni \\ 155100053
}

Fakultas Komputer, 448757165

neni.student@umitra.ac.id

\begin{abstract}
Teknologi yang diungkapkan di sini memaksimalkan ukuran area tampilan yang terkait dengan perangkat seluler dengan berbagai penempatan kamera. Dalam satu perwujudan, kamera ditempatkan di dalam perangkat seluler, dan dapat muncul di luar perangkat seluler saat kamera diaktifkan. ketika kamera tidak aktif, kamera memendek di dalam perangkat seluler, dan menjadi tidak mencolok bagi pengguna. dalam perwujudan lain, kamera terintegrasi ke dalam tampilan perangkat seluler sebagai ikon kamera. ikon kamera terintegrasi.

kamera terintegrasi melayani dua tujuan: untuk merekam gambar, dan bertindak sebagai ikon kamera, yang ketika dipilih mengaktifkan kamera. dengan mengeluarkan kamera dari sisi depan perangkat seluler, atau dengan mengintegrasikan kamera ke layar tampilan perangkat seluler, ukuran layar tampilan perangkat seluler dapat ditingkatkan.
\end{abstract}

Kata Kunci : Paten, Desain Kamera, Vivo APEX

\section{A. INTRODUCTION}

Teknologi yang berkembang pada smartphone semakin maju setiap tahunnya begitu juga dengan hardware yang digunakan. Perkembangan terakhir bisa kita lihat minggu lalu pada ajang Mobile World Congress (MWC) yang diadakan di Barcelona, dalam event tahunan tersebut inovasi yang paling menarik datang dari perusahaan asal China, Vivo. Mereka berhasil menarik perhatian dengan menghadirkan seri vivo apex yang memiliki tampilan layar bezel-less hingga 90 persen tanpa notch, untuk menyiasati desain ini perusahaan menggunakan konsep kamera pop up yang bisa dimunculkan dari sebelah kiri atas. 
Meski belum ada satupun vendor smartphone yang mengusung konsep tersebut, belakangan ini diketahui jika terobosan yang dilakukan oleh Vivo ini sudah terlebih dahulu dipatenkan oleh Essential Phone. Perusahaan yang dipimpin oleh Co-Founder Android tersebut mematenkan konsep yang hampir sama dengan Vivo APEX sejak bulan Mei 2016 dengan nama "Apparatus And Method For Maximizing The Display Of A Mobile Device" dan baru diterima pada bulan Agustus tahun lalu. Baik konsep yang dimiliki oleh Essential maupun Vivo APEX sama-sama mengusung desain smartphone bezel-less tanpa notch dibagian atas layar, bedanya untuk Vivo modul kamera berada di sisi kiri atas sedangkan pada hak paten milik Essential Phone berada di sebelah kanan atas.

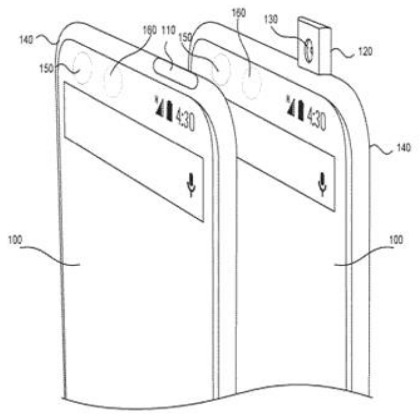

FIG. 1

Vivo berhasil menarik perhatian dengan menghadirkan desain kamera Pop Up pada seri APEX.
Namun hak paten tersebut rupanya sudah dimiliki Essential Phone sejak tahun 2017.

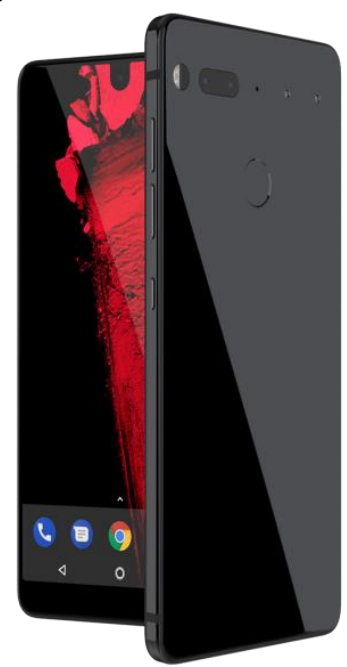

Ponsel Vivo Apex memiliki layar 5,99 "(15,21 $\mathrm{cm}$ ) dengan resolusi layar 1080 x 2160 piksel dan berjalan pada sistem operasi Android v8.0 (Oreo). Perangkat ini didukung oleh inti Octa, prosesor 2,8 $\mathrm{GHz}$ yang dipasangkan dengan 4 GB RAM Sejauh baterai yang bersangkutan memiliki $4000 \mathrm{mAh}$, lebih dari itu, sejauh kamera belakang yang bersangkutan ponsel ini memiliki kamera 12 MP. Sensor lain termasuk sensor Cahaya, sensor Proximity, Accelerometer, Compass, Giroskop. , apakah itu memiliki sensor sidik jari? Ya, tentu saja.Untuk kinerja grafis yang dapat membuat game berjalan lancar, ponsel ini telah mendapat Adreno 630 GPU.Penyimpanan papan berada pada 64 GB dengan opsi untuk memperluas memori dengan Ya Hingga 256 GB. 
VIVO APEX SPECIFICATIONS

> SUMMARY

Performance : Octa Cor

Display : 5,99" (15.21 Cm)

Stronge : $64 \mathrm{~Gb}$

Camera : $12 \mathrm{Mp}$

Battery :4000 Mah

Ram : 4 Gb

Launch Date In India : Agust 23, 2018.

$>$ SPECIAL FEATURES

Fingerprint Sensor Position :

On-Screen

Other Sensors : Light Sensor,

Proximity Sensor,

Accelerometer, Compass,

Gyroscope

Fingerprint Sensor : Yess

$>$ GENERAL

Operating System : Android

V8.0 (Oreo)

Sim Slots : Dual SIM,

GSM+GSM

Model : Apex

Launch Date : August 23, 2018

(Unofficial)

Brand : Vivo

Sim Size : SIM1: Nano SIM2:

Nano (Hybrid)

Network : 4G: Available

(Doesn't Support Indian Bands)

3G: Available, 2G: Available

Fingerprint Sensor : Yess

$>$ MULTIMEDIA

Loudspeaker : Yes

Audio Jack : $3.5 \mathrm{Mm}$

\section{PERFORMANCE}

Chipset : Qualcomm

Snapdragon 845

Graphics : Adreno 630

Processor : Octa Core, $2.8 \mathrm{Ghz}$

Architecture : 64 Bit

Ram : 4 Gb

DISPLAY
Display Type : Oled

Pixel Density : 403 Ppi

Screen Protection : Corning

Gorilla Glass

Screen Size : 5.99 Inches

(15.21 Cm)

Screen Resolution : 1080 X

2160 Pixels

Touch Screen : Yes Capacitive

Touchscreen, Multi-Touch

> STORAGE

User Available Storage : Up To

$106 \mathrm{~Gb}$

Internal Memory : $128 \mathrm{~Gb}$

Expandable Memory : No

Usb Otg Support : Yes

$>$ CAMERA

Settings : Exposure

Compensation, Iso Control

Camera Features : 2 X Digital

Zoom, Auto Flash, Face

Detection, Touch To Focus

Image Resolution : $4000 \mathrm{X}$

3000 Pixels

Sensor Exmor Rs

Autofocus : Yes

Shooting Modes : High

Dynamic Range Mode (Hdr)

Resolution : 25 Mp Front

Camera

Physical Aperture : F2.0

Optical Image Stabilisation :

Yes

Flash : Yes Led Flash

$>$ BATTERY

User Replaceable : No

Quick Charging : Yes Fast

Type: Li-Polymer

Capacity : 3700 Mah

$>$ NETWORK

CONNECTIVITY

Wifi : Yes Wi-Fi 802.11, A/Ac/B/G/N/N $5 \mathrm{ghz}$

Usb Typec : Yes (Doesn`T

Support Micro-Usb) 
Sar Value: Head: 1.390 W/Kg, Body: $0.535 \mathrm{~W} / \mathrm{Kg}$

Nfc : Yes

Network Support : 4g

(Supports Indian Bands), 3g,

$2 \mathrm{~g}$

Gps : Yes With A-Gps,

Glonass

Edge : Available

Wifi Features Mobile Hotspot

Bluetooth : Yes V5.0

Volte : Yes

Usb Connectivity : Mass

Storage Device, Usb Charging

Terungkapnya kabar ini bermula dari kicauan di Twitter yang dibuat oleh seseorang bernama Rafael. Tweet tersebut ditanggapi oleh CEO Essential, Andy Robin, yang membalas dengan tautan hak paten yang sudah diterima perusahaannya. Selain paten tersebut, Essential juga mendaftarkan konsep kamera yang terintegrasi dengan icon yang berada di bagian kiri atas layar. Icon kamera ini memiliki dua fungsi yakni sebagai tombol untuk mengambil foto dan merekam video serta untuk mengaktifkan modul kamera. Dengan terungkapnya informasi hak paten yang dimiliki oleh Essential Phone tersebut tidak lantas membuat Vivo mendapat masalah hukum, karena pada gelaran MWC lalu mereka baru memperkenalkan konsep bukan produk smartphone yang siap untuk dirilis dalam waktu dekat. Sebaliknya, meskipun sudah mengantongi hak paten Essential belum tentu akan merilis smartphone dengan konsep tersebut. Kalau menurut Anda konsep mana yang lebih menarik? Kamera dengan desain Pop Up seperti Vivo APEX atau smartphone dengan tampilan kamera biasa?

\section{B. CONCLUSION}

Teknologi yang diungkapkan di sini memaksimalkan ukuran area tampilan yang terkait dengan perangkat seluler dengan berbagai penempatan kamera. Dalam satu perwujudan, kamera ditempatkan di dalam perangkat seluler, dan dapat muncul di luar perangkat seluler saat kamera diaktifkan. ketika kamera tidak aktif, kamera memendek di dalam perangkat seluler, dan menjadi tidak mencolok bagi pengguna. dalam perwujudan lain, kamera terintegrasi ke dalam tampilan perangkat seluler sebagai ikon kamera. ikon kamera terintegrasi.

kamera terintegrasi melayani dua tujuan: untuk merekam gambar, dan bertindak sebagai ikon kamera, yang ketika dipilih mengaktifkan kamera. dengan mengeluarkan kamera dari sisi depan perangkat seluler, atau dengan mengintegrasikan kamera ke layar tampilan perangkat seluler, ukuran layar tampilan perangkat seluler dapat ditingkatkan.

\section{ACKNOWLEDGEMENT}


University Of Indonesia

University Of Mitra Indonesia

Telkom University

University Of Mellbourne

Saitama University

\section{REFERENCE(Based ISO 690 )}

[2] A. S. Putra, O. M. Febriani, And B. Bachry, "Implementasi Genetic Fuzzy System Untuk Mengidentifikasi Hasil Curian Kendaraan Bermotor Di Polda Lampung," J. Sist. Inf. Dan Manaj. Basis Data, Vol. 1, No. 1, Pp. 21-30, 2018.

[3] O. M. Febriani And A. S. Putra, "Sistem Informasi Monitoring Inventori Barang Pada Balai Riset Standardisasi Industri Bandar Lampung," J. Inform., Vol. 13, No. 1, Pp. 90-98, 2014.

[4] Putra, Arie Setya. "2018 Artikel Struktur Data, Audit Dan Jaringan Komputer." (2018).

[5] Putra, A. S. (2018, July 17). Paperplain Fundamental Create Application With Borland Delphi 7.0 University Of Mitra Indonesia. Retrieved From Osf.Io/Pbrn9.

\section{E. REFERENCE(Based APA )}

Putra, A. S., Aryanti, D. R., \& Hartati, I. (2018, November). Metode SAW (Simple Additive Weighting) sebagai Sistem Pendukung Keputusan Guru Berprestasi (Studi Kasus: SMK Global Surya). In Prosiding Seminar Nasional Darmajaya (Vol. 1, No. 1, pp. 85-97).

Sari, D. P., Febriani, O. M., \& Putra, A. S. (2018, November). Perancangan Sistem Informasi SDM Berprestasi pada SD Global Surya. In Prosiding Seminar Nasional Darmajaya (Vol. 1, No. 1, pp. 289-294).

Putra, A. S. (2018). Paperplain: Execution Fundamental Create Application With Borland Delphi 7.0 University Of Mitra Indonesia.

Putra, A. S., Sukri, H., \& Zuhri, K. Sistem Monitoring Realtime Jaringan Irigasi Desa (JIDES) Dengan Konsep Jaringan Sensor Nirkabel. IJEIS (Indonesian Journal of Electronics and Instrumentation Systems), 8(2), 221232.

Darmawan, A., Yuliawati, D. Marcella, O., \& Firmandala, R. (2016). Sistem Absensi dan Pelaporan Berbasis Fingerprint dan SMS Gateway. EXPLORE, 7(1).

Febriani, O. M., Wahyuni, T., \& Yusuf, S. (2017). DESIGN OF WEBSITE-BASED INFORMATION SYSTEM FOR EDOCUMENT ADMINISTRASI IN THE COMMUNITY SERVICE UNIT (A Case Study at Rajabasa District). INTERNATIONAL JOURNAL OF COMPUTERS \& TECHNOLOGY, 16(7), 7010-7020. 
Febriani, O. M., \& Wahyuni, T. (2017, October). PERANCANGAN SISTEM E-DOCUMENT ADMINISTRASI LOGBOOK PENELITIAN PADA UNIT LAYANAN DI BANDAR LAMPUNG. In Prosiding Seminar Nasional Darmajaya (Vol. 1, No. 1, pp. 187-194).

Febriani, O. M., \& Permadi, A. B. (2017). Implementasi Sistem Aplikasi Data Bimbingan dan Pelanggaran Siswa pada Sekolah Menengah Atas di Lampung Tengah dengan Metode Analisis dan Desain Sistem Terdistribusi (SSAD). EXPERT, 7(1).

Febriani, O. M., \& Ambarwati, L. (2015). PERANCANGAN APLIKASI PENGOLAHAN DATA PENJUALAN UKM KELANTING KHAS TELO DESA SIDOHARJO KECAMATAN JATI AGUNG KABUPATEN LAMPUNG SELATAN. Jurnal Teknologi Informasi dan Bisnis Pengabdian Masyarakat Darmajaya, 1(1), 77-95.

Febriani, O. M. (2015). Rancang Bangun Aplikasi Ecommercemenggunakan Freewebstore pada UKM Kelanting di Desa Sidoharjo Lampung Selatan. Prosiding Sembistek 2014, 1(02), 446-458. 